DOI: https://doi.org/10.15407/preislamic2021.02.069

UDC 94(32)

\title{
THE DELIBERATE “MISTAKES” IN A DEMOTIC VERSION OF THE RAFIA DECREE
}

\author{
A. L. Zelinskyi \\ DSc (History) \\ Acting Leading Researcher \\ Department of History of Asia and Africa \\ State Institution "Institute of World History of the National Academy of Sciences of Ukraine" \\ 5 Leontovich Str., Kyiv, 01054, Ukraine \\ z-al@ukr.net
}

After the Egyptian victory at the Battle of Rafia ( $22^{\text {nd }} J u n e ~ 217$ BC) and the favorable finish of the Fourth Syrian War for the country of the Nile (221-217 BC), the local priestly synod accepted a decree in honor of a ruling pharaoh - Ptolemy IV Philopator $\left(15^{\text {th }}\right.$ November $\left.217 \mathrm{BC}\right)$. We are talking about the so-called Rafia Decree (Cairo 50048; cf. CG 31088). Its text is best preserved in a demotic version. A demotic text of this document contains two points that are usually considered by the modern researchers as the mistakes of the performers of the inscription. The first point is the naming of Ptolemy IV as the son of Arsinoe, while Berenice II was the real mother of this king. The second point is an unprecedented naming as pharaoh of Antiochus III - of the ruler, of the kingdom of the Seleucids, which was hostile to Egypt; besides, his name was partially framed in the royal cartouche in a few cases. In author's opinion, both points were the result of a planned decision. The reason for the deliberate replacement of Berenice's name with "Arsinoe", another popular name of the Ptolemaic royal family, was the reluctance to remind of the act of maternal murder, actually committed by Ptolemy IV. However, the name of Ptolemy IV's mother is indicated correctly in a fragmentary hieroglyphic version of the decree. I think that it has occurred in consequence of the prohibition of deliberately blatant distortion of the truth in the use of a sacred hieroglyphic writing. The naming of Antiochus III as Pharaoh may have been a reflection of the first signs of dissatisfaction of the local population of Egypt with Ptolemy IV's insufficient attention to the duties of the lord of the Two Lands. In such an extravagant way, the representatives of the Egyptian priesthood hinted at the possibility of the appearance of another pharaoh, who could be the closest relative of Philopator in the female line - Antiochus III.

Keywords: the Rafia Decree, Ptolemy IV, Arsinoe, Berenice II, Antiochus III

\section{А. Л. Зелінський \\ НАВМИСНІ "ПОМИЛКИ" В ДЕМОТИЧНОМУ ВАРІАНТІ ДЕКРЕТУ РАФІЇ}

У 217 р. (тут і далі - до Р. Х.) завершилася IV Сирійська війна, яка 3221 р. велася між царем держави Селевкідів Антіохом III і володарем елліністичного Єгипту Птолемеєм IV Філопатором ${ }^{1}$. Кульмінацією та водночас переломним моментом цього конфлікту стала переможна для Сгипту грандіозна битва, що відбулася 22 червня 217 р. на самих підступах до Країни Нілу біля палестинського містечка Рафії (CG 31088; 50048; Polyb. V, 79-86; 107; Dan. XI, 11-12; Mac. I, 1-5; III, 14; Strab. XVI,

${ }^{1}$ Про IV Сирійську війну в більш доцільних широких хронологічних межах див.: [Winnicki 1989, 88-112; Huss 2001, 386-404; Grabowski 2010, 214-274; Pfeiffer 2017, 102-108; 3eлінський 2020, 185-191, 488-494, прим. 1639-1694]. 
II, 31; P. Trog., Prol. XXX; Just. XXX, 1; Plut., De Sollert. 17; Ael., De Nat. Anim. VII, 44; Porphyr. Fragm. 44 = Hier. Com. In Dan. XI, 11-12). До того ж на завершальній стадії цієї битви Птолемей IV, подібно до фараонів-войовників XVIII чи XIX династії, особисто очолив переможну атаку військового корпусу, що складався з корінних єгиптян [Hölbl 2001, 131; Manning 2010, 101; Grabowski 2014, 45]. Оскільки Антіох III виступав у цій війні як безумовний агресор, який зазіхав на підвладні Єгипту території (див. прим. 1), Птолемей Філопатор сприймався єгиптянами як класичний фараон, що, подібно до бога Гора, блискуче виконав свій сакральний обов'язок із захисту Країни Нілу від сил хаосу (див., наприклад: [Зелінський 2020, 200-202, 504-505, прим. 1787-1802])2.

Цей стан речей знайшов яскраве відображення у формі урочистого рішення загальноєгипетського жрецького синоду, який було скликано в Мемфісі в листопаді 217 p. [Grabowski 2014, 44-46]. Це рішення, ухвалене єгипетським жрецтвом на честь перемоги Філопатора в IV Сирійській війні (Cairo CG 31088; 50048), дістало в наукових колах назву “Декрет Рафії, оскільки найяскравіша його частина містить опис ролі царя під час вищезгаданої битви ${ }^{3}$.

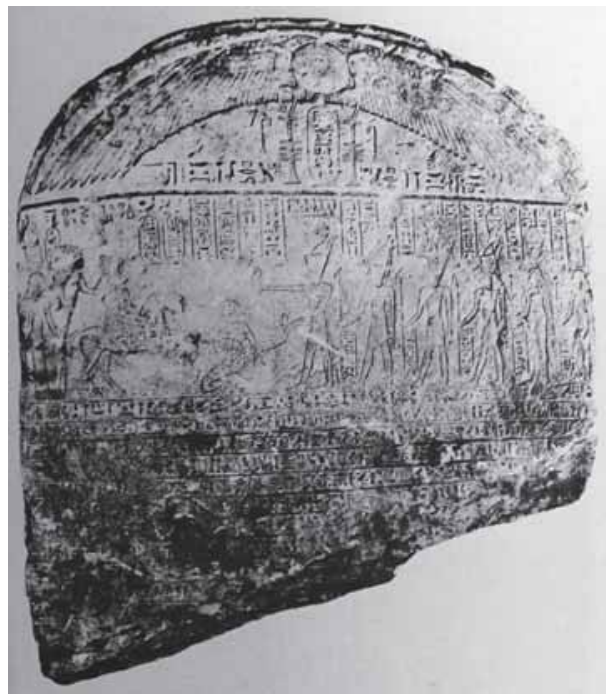

Мал. 1а. Ієрогліфічний текст Декрету Рафії (Cairo CG 50048) (за [Thissen 1966, 85])

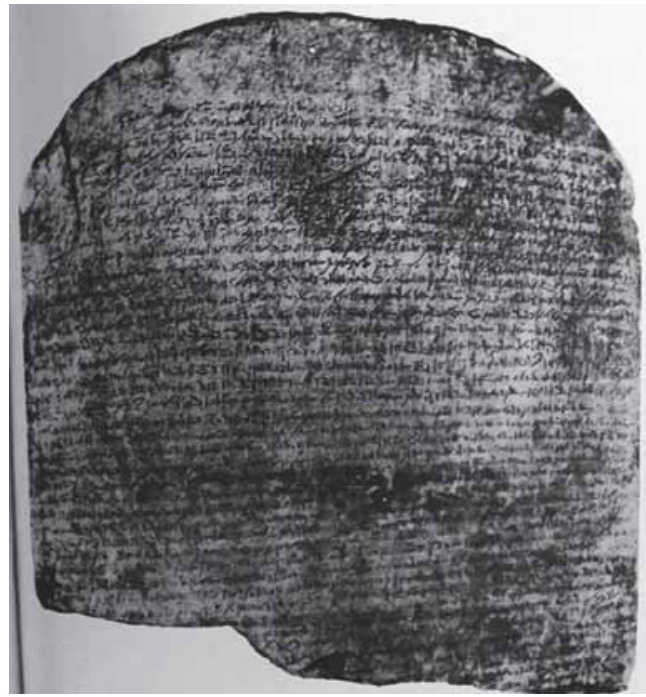

Мал. 1б. Демотичний текст Декрету Рафії (Cairo CG 50048) (за [Thissen 1966, 87])

Зміст цієї пам'ятки дійшов до нас у трьох екземплярах, викарбуваних на кам'яних стелах, які були знайдені, відповідно, у Мемфісі (Сairo CG 31088), Пифомі (Cairo CG 50048) (мал. 1a) і Туфіоні (суч. Ель-Тод) (див.: [Hölbl 2001, 163, 174, n. 23])4 . Кожен 3 них, подібно до інших постанов цього гатунку, являє собою своєрідну трилінгву (пор., наприклад: [Панов 2020, 329]). Проте 3 трьох писемних варіантів

${ }^{2}$ На відміну від греко-македонських басилевсів, єгипетські фараони насамперед відігравали роль не воїнів-завойовників, а воїнів-захисників [Pfeiffer 2017, 89].

${ }^{3}$ Під час роботи над цим дослідженням я використовував видання й переклади вищезгаданого декрету, здійснені В. Шпігельбергом і Х.-Й. Tiссеном [Spiegelberg 1925, passim; Thissen 1966, passim].

${ }^{4}$ Останній з вищеперерахованих екземплярів Декрету Рафії зберігся лише у формі фотографії, яка й лягла в основу його публікацій [Schwartz, Malinine 1960, 81-83, 87-90]. 
нашого документа: ієрогліфічного, демотичного та давньогрецького - добре зберігся лише другий. Грецький текст на усіх стелах було майже повністю втрачено, тоді як від ієрогліфічного в його сукупності залишилося кілька рядків і розрізнених фрагментів (пор.: [Hölbl 2001, 163, 174, n. 23; Klotz 2013, 45]). Окрім цього, слід зазначити, що демотичний текст найкраще зберігся на Питомській стелі (див. мал. 1б). Тому не дивно, що, зрештою, демотичний варіант декрету, вирізьблений на питомському артефакті, й був узятий сучасними дослідниками за основу для вивчення цього важливого документа (пор.: [Klotz 2013, 45]).

Саме в демотичному тексті цього документа є декілька специфічних особливостей, що викликали мій інтерес. Йдеться про два моменти, які в сучасній історіографії, як правило, вважаються технічними помилками виконавців напису (див. нижче). Перший момент полягає в найменуванні Птолемея IV сином Арсиної (Сairo CG 50048, 7-8, також див. мал. 1б) [Spiegelberg 1925, 6; Thissen 1966, 10-13, 51], тоді як справжньою матір'ю цього царя була Береніка II (див., наприклад: Polyb. XV, 25; Zenob., Proverb. III, 94; а також нижче). Другий момент являє собою несподіване наділення титулом фараона володаря ворожого Сгипту царства Селевкідів - Антіоха III (див. вище); до того ж ім'я останнього в кількох випадках було частково обрамлене в царський картуш (Cairo CG 50048, 10, 12, 15, 17, 25; також див. мал. 1б) (пор.: [Spiegelberg 1925, 7, 16-17; Thissen 1966, 12-13; Vittmann 2005, 199-200; Ладынин 2017, 447]). На мій погляд, в обох випадках ми маємо справу зі свідомими діями укладачів декрету.

Почнемо з плутанини з іменами. У цьому зв'язку варто згадати, що Птолемей IV ще на першому році свого правління вбив або як мінімум інспірував убивство власної матері Береніки, підозрюючи останню в підтримці гіпотетичних владних зазіхань 3 боку його молодшого брата Магаса (Polyb. V, 36; XV, 25; Zenob., Proverb. III, 94; пор. Plut. Cleom. 33; Just. XXIX, 1; XXX, 1). Водночас матеревбивця прагнув уникати офіційних згадок імені Береніки до 211/210 р., коли він заснував культ іiі особи (Zenob. Proverb. III, 94) (пор.: [Hölbl 2001, 105, 170; Huss 2001, 453; Grabowski 2014, 40-41; Pfeiffer 2017, 98-99]). На мою думку, саме аспекти вищезгаданої ситуації й були враховані представниками єгипетської жрецької еліти, які були причетні до прийняття урочистої постанови. Заміна імені справжньої матері Філопатора Береніки на інше династичне ім'я Арсиноя була пов'язана 3 небажанням укладачів декрету зайвий раз акцентувати увагу як на її особі, так і на самому акті матеревбивства, який, м'яко кажучи, не прикрашав переможця в битві при Рафії5.

Зрештою, просто важко собі уявити, що єгипетські первосвященники, які, безумовно, були чудово обізнані зі станом речей при александрійському дворі ${ }^{6}$, могли виявити настільки невибачне невігластво у справах генеалогії керівного фараона. Доказом цьому може бути ієрогліфічний варіант постанови, при написанні якого

\footnotetext{
${ }^{5}$ Аналогічний вчинок, здійснений богом Гором щодо його матері Есет, у єгипетських міфологічних текстах характеризується як “лиха справа” і “злочин” (пор.: [Панов 2018, 123, 242]). Цікаво, що Плутарх, обізнаний з історією про Горове матеревбивство, з огляду на невідповідність такого вчинку наскрізь позитивному образу цього божества у своїй розповіді замінив обезголовлення Ісіди/Есет на позбавлення іiі корони (Plut., De Is. 19).

6 Зокрема, не варто забувати, що до ухвалення знаменитого Мемфіського (Розеттського) декрету 196 р. представники єгипетського жрецтва мусили в обов’язковому порядку щорічно відвідувати Александрію [Панов 2020, 342]. Перша згадка про це зобов'язання міститься в Александрійському синодальному декреті 243 р. [Панов 2020, 307-308].
} 
ім'я матері Птолемея IV було вказано правильно (Cairo CG 50048, 5-6; також див. мал. 1a) [Thissen 1966, 13, 51]. До того ж, як і у випадку “Арсиної” демотичного варіанта, "Береніка" ієрогліфіки, з мого погляду, була цілком доречною та зрозумілою. На відміну від загальнопоширеної демотичної писемності, що не мала сакрального статусу, більш складна й, відповідно, менш поширена ієрогліфіка розглядалася єгиптянами як “слова бога", тобто несла в собі безумовне сакральне навантаження [Чегодаев 2014, 257-264; пор.: Панов 2020, 329]. Відповідно, текст, відображений у формі священного письма, не міг містити у собі будь-які відверті свідомі викривлення істинного стану речей. Отже, при записі Декрету Рафії "словами бога" цілком очікувано було вказано справжнє (кон'юнктурно незручне) ім'я матері Птолемея $\mathrm{IV}^{7}$. Враховуючи ж те, що ієрогліфічний варіант постанови, на відміну від демотичного, не призначався для широких мас освічених єгиптян, вищезазначений стан речей ії укладачів цілком влаштовував ${ }^{8}$.

Більш складним для розуміння видається другий зі згаданих на цих сторінках епізодів (див. вище). Найменування чужоземного, до того ж ворожого Єгипту правителя фараоном, не кажучи вже про бодай часткове обрамлення його імені царським картушем, являє собою безпрецедентний випадок в історії Країни Нілу9. Жодне із запропонованих пояснень сутності цього феномену не можна вважати задовільним. 3 мого погляду, у цьому разі не могло йтися ні про помилку укладачів відповідного тексту [Vittmann 2005, 200], ні про визнання факту примирення Філопатора з Антіохом III, так само як і про адаптацію до вимог елліністичного дипломатичного протоколу [Pfeiffer 2017, 141]. Кажучи про неможливість подібної помилки, слід мати на увазі банальну нездатність із боку навіть єгипетських різьбярів бодай на підсвідомому рівні зафіксувати існування у світі ще одного правителя, який мав би рівний статус із володарем їхньої країни, наділеним яскраво вираженою унікальною сакральністю (пор., наприклад: [Зелінський 2020, 63, 290-291, nрим. 315-316]). Також не могло бути мови про підняття статусу іноземного монарха до рівня володаря Обох земель під час укладення між ними мирної угоди, особливо коли йшлося про текст для, так би мовити, внутрішнього користування ${ }^{10}$. Нарешті, замість того щоб титулувати Антіоха III фараоном, єгипетське жрецтво могло використати більш звичні й доречні в цьому разі терміни: “правитель Азії, “правитель чужих земель” або просто “величність” чи “великий” (див., наприклад:

\footnotetext{
${ }^{7}$ На жаль, нам досі невідомо, яке ім'я в цьому випадку містив грецький варіант постанови. Визнаю, що ця обставина додає моєму припущенню певного ступеня умовності.

8 цим висновком під час приватного листування погодився М. А. Чегодаєв (Москва).

${ }^{9}$ Використання терміна “фараон” у випадках демотичної передачі перського титулу “великий цар”, датованих V-IV ст. [Ладынин 2017, 447; Панов 2021a, 311], з мого погляду, є цілком доречним, оскільки обумовлюється фактом тогочасного перебування Сгипту у складі держави Ахеменідів (пор.: [Vittmann 2005, 200]). Водночас я вважаю недоречним припущення М. В. Панова, згідно з яким множина титулу “несу” (nsw) в кол. 5 Саїської стели часів Птолемея II Філадельфа стосувалася не попередників зазначеного царя на престолі володарів Верхнього і Нижнього Сгипту, а його сучасників-епігонів: Антігона Гоната й Антіоха I Сотера [Панов 2019, 168, прим. 153]. У цьому разі слід мати на увазі, що існування на землі бодай одного “додаткового” несу, не кажучи вже про декількох, кардинально розбігається з усталеним єгипетським світосприйняттям.

${ }^{10}$ Прикладом цього може бути єгипетська риторика, пов'язана з укладенням миру між Рамзесом II і хетським царем Хаттусілі III [Панов 2021b, 301].
} 
Навмисні “помилки” в демотичному варіанті Декрету Рафії

Naples 1035, 8; Cairo CG 22181) (пор.: [Vittmann 2005, 200; Панов 2017, 180, 194, 196, 207; Панов 2021b, 301-302; Ладынин 2017, 387-400, 459-461]).

На мою думку, якщо у випадку з використанням імені Арсиноя ми маємо справу зі своєрідною демонстрацією лояльності єгипетського жрецтва щодо Птолемея IV, то у випадку з “фараоном Антіохом” йдеться про завуальоване застереження, що межувало з погрозою. Малася на увазі обережна вказівка на об’єктивну можливість перенесення царської сакральності на особу молодого Селевкіда, який був найближчим родичем (троюрідним братом) Філопатора по материнській лінії (пор. App., Syr. 3; також див. мал. 2). 3 одного боку, протягом першого року правління Птолемей IV винищив усіх своїх близьких родичів чоловічої статі (див., наприклад: [Зелінський 2020, 184, 486, прим. 1625-1628]). 3 іншого-Антіох III 3 огляду на сукупність прав і можливостей [Зелінський 2020, 187-188, 490-491, прим. 1659] був найімовірнішим претендентом на спадок бездітного на той час Філопатора (пор.: [Зелінський 2020, 208-209]) ${ }^{11}$. Зокрема, генеалогічна причетність до престолу з боку цариці з єгипетського погляду становила цілком достатню передумову для передання влади над Країною Нілу ${ }^{12}$.

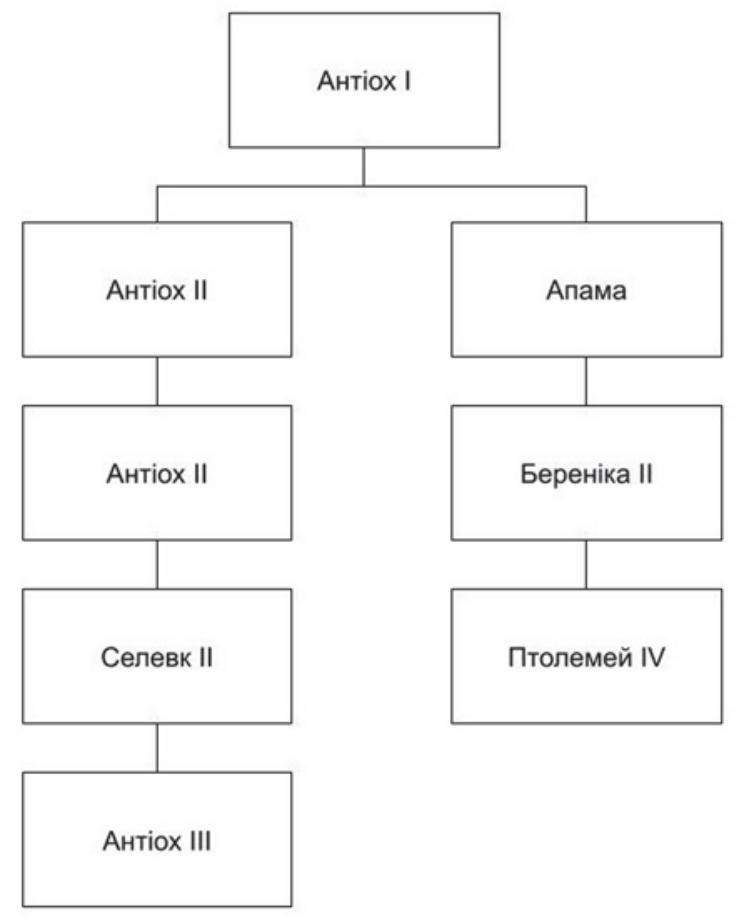

Мал. 2. Схема споріднення між Антіохом III і Птолемеєм IV

${ }^{11}$ Цікаво, що менш ніж через 15 років після ухвалення Декрету Рафії одного з провідних функціонерів початку царювання малолітнього Птолемея V Тлеполема звинуватять у намірі передати Єгипет все тому ж Антіоху III (Polyb. XV, 25).

${ }^{12}$ Майже через 50 років після Рафії інший родич Птолемеїв по материнській лінії, який на короткий час заволодів Сгиптом, Антіох IV під час своєї експансії в одному господарському папірусі також маркувався царським картушем, що знаходить певне підтвердження у творах Порфирія і св. Іероніма (Porphyr. Fragm. $49=$ Hier. Com. In Dan. XI, 21) [Hölbl 2001, 144-148; Huss 2001, 547-562; Blasius 2007, 75-107; пор. Pfeiffer 2017, 141-142]. 
Схоже, що представники місцевого жрецтва справді могли мати підстави вдатися до подібного неординарного прийому, сподіваючись, що їхній натяк буде в належний спосіб донесено і витлумачено цареві. Як видно з тексту знаменитого Мемфіського (Розеттського) синодального декрету 196 р. [Панов 2020, 318-373], син і наступник Філопатора Птолемей V Епіфан зменшив грошовий внесок, який мали сплачувати державі єгипетські жерці-уаб під час їхнього висвячення ${ }^{13}$. До того ж цей внесок було зменшено до розмірів, зафіксованих на момент першого року царювання Птолемея IV (BM, 24, 16 = OGIS, 90, 16) [Панов 2020, 341]. Отже, близько 2-го року царювання Птолемея IV жрецькі грошові внески з огляду на воєнну загрозу (пор. вище) було збільшено до невідомого нам розміру ${ }^{14}$. Імовірно, цей захід держава окреслювала як тимчасове явище. Проте після перемоги під Рафією сума жрецьких внесків не зменшилася. Відповідно, представники місцевого жрецтва дали зрозуміти цареві, що в разі нехтування їхніми інтересами в Сгипті теоретично може 3'явитися інший фараон ${ }^{15}$. Однак, як випливає зі змісту Розеттського декрету, жрецький натяк, зроблений Філопатору, так і не було почуто в Александрії16.

\section{УМОВНІ СКОРОЧЕННЯ}

BM - British Museum.

Cairo CG - Catalogue général des antiquités égyptiennes du Musée du Caire.

Naples - Museo archeologico Nazionale di Napoli.

OGIS - Orientis Graeci inscriptiones Selectae.

\section{ЛIТЕРАТУРА}

Зелінський А. Л. Від басилевсів-фараонів до фараонів-басилевсів: перші 100 років птолемеївської монархії. Вінниця - Київ, 2020.

${ }^{13}$ На згадку в декреті лише жерців-уаб вказує М. В. Панов [Панов 2020, 341]. До того ж цікаво, що, згідно з перекладами російського дослідника, до цієї категорії єгиптяни відносили й епонімних жерців державного культу Александра і Птолемеїв [Панов 2020, 295, 333-334]. Ситуація з іншими категоріями жрецтва й досі невідома (пор.: [Veïsse 2004, 219 220; Huss 2011, 195; Gladic 2015, 65-67; Wespi 2016, 182]).

${ }^{14}$ Щодо інтерпретації тексту декрету, згідно з якою в ньому йшлося про перший рік самого Птолемея V, див., наприклад: [Veïsse 2004, 219; Gladic 2015, 65-67].

${ }^{15}$ Не виключаю, що парадоксальна ідея найменування Антіоха III фараоном могла спасти на думку комусь із єгипетських жерців за асоціацією з "Поемою Пентаура" - літературним твором, присвяченим особистому героїзму Рамсеса II в битві під Кадешем. Подібно до молодого Селевкіда, який скаржився, що військо звело нанівець його особисту перемогу над лівим флангом птолемеївської армії під Рафією (Polyb. V, 85), молодий Рамсес II протиставляє власний героїчний прорив з ворожого оточення, який він позиціонує як особисту перемогу над хетським царем, боягузливості власного війська (пор.: [Стучевский 1984, 23 33; Morenz, Popko 2010, 114-117; Панов 2021b, 298-299]). Відповідна паралель, цілком імовірно, могла виникнути в уяві когось з укладачів Декрету Рафії, які були чудово обізнані як 3 реаліями нещодавньої битви [Зелінський 2020, 506-507, прим. 1809], так і з творами власної класичної поезії. На останню обставину вказують непрямі ремінісценції опису битви під Кадешем, наявні в тексті вищезгаданої постанови (пор.: [Thissen 1966, 54]).

${ }^{16}$ Логічним наслідком подальшого недбалого ставлення Птолемея IV до потреб місцевого населення стало т. зв. Велике повстання, що розпочалося наприкінці його правління й тривало протягом 207/206-186 рр. Див., наприклад: [Зелінський 2020, 207-209, 514-516, прим. 1867-1878]. 
Ладынин И. А. Начало македонского времени в категориях традиционного мировоззрения древних египтян конца IV - начала III вв. до н. э.: в 2-х т. Т. 1: Дис. докт. ист. наук: 07.00.03 / Московский государственный университет. Москва, 2017.

Панов М. В. Документы персидского и греко-римского периодов. Новосибирск, 2019.

Панов М. В. Историко-биографические и мифологические надписи позднего времени. Новосибирск, 2017.

Панов М. В. Исторические надписи из Куша и Кемета (I тыс. до н. э.). Новосибирск, 2020.

Панов М. В. Источники по древнеегипетской истории в переводах на русский язык. Каталог. Новосибирск, 2021a.

Панов М. В. Легенды, мифы и гимны. Доклады. Новосибирск, 2018.

Панов М. В. Письма, наставления и документы эпохи Рамессидов. 2-е издание, исправленное. Новосибирск, $2021 b$.

Стучевский И. А. Рамсес II и Херихор. Из истории древнего Египта эпохи Рамессидов. Москва, 1984.

Чегодаев М. А. На каком языке говорил бог? // Доісламський Близыкий Схід: історія, релігія, культура. Збірник наукових статей / Під ред. М. О. Тарасенка. Київ, 2014.

Blasius A. Antiochos IV. Epiphanes. Basileus und Pharao Ägyptens? Porphyrios und die polybianische überlieferung // Ägypten unter fremden Herrschern zwischen persischer Satrapie und römischer Provinz / Hg. St. Pfeiffer. Frankfurt am Main, 2007.

Gladic D. Das Dekret von Memphis (196 v. Chr.). Kommentar X Auswertung. Dis... Doct. Phil. / der Universität Trier. Trier, 2015.

Grabowski T. Ostatni Triumf Ptolemeuszy. Czwarta Wojna syryjska (221217 p. n. e.). Kraków, 2010.

Grabowski T. Polityka religijna Ptolemeusza IV Filopatora -wybrane aspekty // Klio (Pl.). 2014. Vol. 30/31.

Hölbl G. A History of the Ptolemaic Empire: Transl. from German. London - New York, 2001.

Huss W. Ägypten in hellenistischer Zeit: 332-30 v. Chr. München, 2001.

Huss $W$. Verwaltung des ptolemäischen Reichs. München, 2011.

Klotz D. Who was with Antiochos III at Raphia? Revisiting the Hieroglyphic Versions of the Raphia Decree (CG 31088 and 50048) // Chronique d'Égypte. 2013. T. 87.

Manning $J$. The Last Pharaohs. Egypt under the Ptolemies, 305-30 BC. Princeton; Oxford, 2010.

Morenz L., Popko L. The Second Intermediate Period and the New Kingdom // A companion to Ancient Egypt / Ed. by A. Lloyd. Vol. I. Oxford, 2010.

Pfeiffer St. Die Ptolemäer: im Reich der Kleopatra. Stuttgart, 2017.

Schwartz J., Malinine M. Pierres d'Égypte// Revue Archéologique. 1960. T. 1.

Spiegelberg $W$. Beiträge zur Erklärung des neuen dreisprachigen Priesterdekretes zu Ehren des Ptolemaios Philopator. München, 1925.

Thissen H.-J. Studien zum Raphiadekret. Meisenheim am Glan, 1966.

Veïsse A.-E. Les "revoltes egyptiennes". Recherches sur les troubles interieurs en Egypte du regne de Ptolemee III a la conquete romaine. Leuven - Paris - Dudley (MA), 2004. 
А. Л. Зелінський

Vittmann G. "Feinde" in den ptolemäischen Synodaldekreten. Mit einem Anhang: Demotische Termini für "Feind", "Rebell", "rebellieren" // Feinde und Aufrührer. Konzepte von Gegnerschaft in ägyptischen Texten besonders des Mittleren Reiches / Hg. H. Felber. Stuttgart - Leipzig, 2005.

Wespi F. Das Gesetz der Tempel: Ein Vorbericht zu den Priesternormen des demotischen Papyrus Florenz PSI inv. D 102 // Ägyptologische Tempeltagung: Ägyptische Tempel zwischen Normierung und Individualität. München, 29.-31. August 2014. Königtum, Staat und Gesellschaft früher Hochkulturen 3, 5: Akten der ägyptologischen Tempeltagungen / Hg. M. Ullmann. Wiesbaden, 2016.

Winnicki J.-K. Operacje wojskowe Ptolemeuszów w Syrii. Warszawa, 1989.

\section{REFERENCES}

Zelins'kyy A. L. (2020), Vid basylevsiv-faraoniv do faraoniv-basylevsiv: pershi 100 rokiv ptolemeyivs 'koyi monarkhiyi, "Tvory", Vinnytsya and Kyiv. (In Ukrainian).

Ladynin I. A. (2017), Nachalo makedonskogo vremeni v kategoriyakh traditsionnogo mirovozzreniya drevnikh egiptyan kontsa IV-nachala III vv. do n. e.: v 2-kh t. T. 1: Dis... dokt. ist. nauk: 07.00.03, Moskovskiy gosudarstvennyy universitet, Moscow. (In Russian).

Panov M. V. (2019), Dokumenty persidskogo, i greko-rimskogo periodov, M. V. Panov, Novosibirsk. (In Russian).

Panov M. V. (2017), Istoriko-biograficheskiye i mifologicheskiye nadpisi pozdnego vremeni, M. V. Panov, Novosibirsk. (In Russian).

Panov M. V. (2020), Istoricheskiye nadpisi iz Kusha i Kemeta (I tys. do n. e.), M. V. Panov, Novosibirsk. (In Russian).

Panov M. V. (2021), Istochniki po drevneyegipetskoy istorii v perevodakh na russkiy yazyk. Katalog, M. V. Panov, Novosibirsk. (In Russian).

Panov M. V. Legendy, mify i gimny. Doklady. Novosibirsk: M. V. Panov, 2018. (In Russian).

Panov M. V. (2021), Pis'ma, nastavleniya i dokumenty epokhi Ramessidov. 2-e izdaniye, ispravlennoye, M. V. Panov, Novosibirsk. (In Russian).

Stuchevskiy I. A. (1984), Ramses II i Kherikhor. Iz istorii drevnego Egipta epokhi Ramessidov, Nauka, Moscow. (In Russian).

Chegodayev M. A. (2014), "Na kakom yazyke govoril bog?”, M. O. Tarasenko (ed.), Doislams 'kyy Blyz'kyy Skhid: istoriya, relihiya, kul tura. Zbirnyk naukovykh statey, Kyiv, pp. 257-64. (In Russian).

Blasius A. (2007), “Antiochos IV. Epiphanes. Basileus und Pharao Ägyptens? Porphyrios und die polybianische überlieferung“, in St. Pfeiffer (ed.), Ägypten unter fremden Herrschern zwischen persischer Satrapie und römischer Provinz, Verlag Antike, Frankfurt am Main, pp. 75-107.

Gladic D. (2015), Das Dekret von Memphis (196 v. Chr.). Kommentar X Auswertung: Dis... Doct. Phil., der Universität Trier, Trier.

Grabowski T. (2010), Ostatni Triumf Ptolemeuszy. Czwarta Wojna syryjska (221217 p. n. e.), Historia Jagellonica, Kraków.

Grabowski T. (2014), "Polityka religijna Ptolemeusza IV Filopatora -wybrane aspekty", Klio (P1.), Vol. 30/31, pp. 37-49. 
Навмисні “помилки” в демотичному варіанті Декрету Рафії

Hölbl G. (2001), A History of the Ptolemaic Empire, translated by T. Saavedra, Routledge, London and New York.

Huss W. (2001), Ägypten in hellenistischer Zeit: 332-30 v.Chr., C. H. Beck, München.

Huss W. (2011), Verwaltung des ptolemäischen Reichs, C. H. Beck, München.

Klotz D. (2013), "Who was with Antiochos III at Raphia? Revisiting the Hieroglyphic Versions of the Raphia Decree (CG 31088 and 50048)", Chronique d'Égypte, T. 87, pp. 45-59.

Manning J. (2010), The Last Pharaohs. Egypt unter the Ptolemies, 305-30 BC, Princeton University Press, Princeton, Oxford.

Morenz L. and Popko L. (2010), "The Second Intermediate Period and the New Kingdom", in A. Lloyd (ed.), A Companion to Ancient Egypt, Vol. I, Blackwell Publishing, Oxford, pp. 101-19.

Pfeiffer St. (2017), Die Ptolemäer: im Reich der Kleopatra, W. Kohlhammer GmbH, Stuttgart.

Schwartz J. and Malinine M. (1960), "Pierres d'Égypte", Revue Archéologique, T. 1, pp. 77-90.

Spiegelberg W. (1925), Beiträge zur Erklärung des neuen dreisprachigen Priesterdekretes zu Ehren des Ptolemaios Philopator, Verlag der Bayerischen Akademie der Wissenschaften, München.

Thissen H.-J. (1966), Studien zum Raphiadekret, A. Hain, Meisenheim am Glan.

Veïsse A.-E. (2004), Les "revoltes egyptiennes". Recherches sur les troubles interieurs en Egypte du regne de Ptolemee III a la conquete romaine, Peeters, Leuven, Paris and Dudley (MA).

Vittmann G. (2005), “'Feinde' in den ptolemäischen Synodaldekreten. Mit einem Anhang: Demotische Termini für 'Feind', 'Rebell', 'rebellieren'”, in H. Felber (ed.), Feinde und Aufrührer. Konzepte von Gegnerschaft in ägyptischen Texten besonders des Mittleren Reiches, Verlag der Sächsischen Akademie der Wissenschaften zu Leipzig, Stuttgart and Leipzig, pp. 198-219.

Wespi F. (2016), "Das Gesetz der Tempel: Ein Vorbericht zu den Priesternormen des demotischen Papyrus Florenz PSI inv. D 102", in M. Ullmann (ed.), Ägyptologische Tempeltagung: Ägyptische Tempel zwischen Normierung und Individualität. München, 29.31. August 2014. Königtum, Staat und Gesellschaft früher Hochkulturen 3, 5: Akten der ägyptologischen Tempeltagungen, Harrassowitz Verlag, Wiesbaden, pp. 179-94.

Winnicki J.-K. (1989), Operacje wojskowe Ptolemeuszów w Syrii, Wyd-wo Un-tu warszawskiego, Warszawa.

\section{А. Л. Зялінскі \\ НАЎМЫСНЫЯ "ПАМЫЛКІ" \\ Ў ДЭМАТЫЧНЫМ ВАРЫЯНЦЕ ДЭКРЭТА РАФІІ}

Пасля егіпецкай перамогі ў бітве пры Рафіi (22 чэрвеня 217 г. да н. э.) і спрыяльнага для краіны Ніла сканчэння IV Сірыйскай вайны (221-217 гг. да н. э.) мясцовы жрэцкі сінод прыняў урачыстую пастанову ў гонар кіруючага фараона - Пталямея IV Філапатара (15 лістапада 217 г. да н. э.). Гаворка ідзе пра так званы Дэкрэт Рафіi, тэкст якога лепш за ўсё захаваўся ў дэматычным варыянце (Cairo CG 31088; пар. CG 50048). Менавіта ў дэматычным тэксце гэтага дакумента прысутнічаюць два моманты, якія ў сучаснай гістарыяграфіi, як правіла, лічацца тэхнічнымі хібамі выканаўцаў надпісу. Першы момант заключаецца ў 
А. Л. Зелінський

найменні Пталямея IV сынам Apсіноі, калі ж сапраўднай маці ўказанага цара была Берэніка II. Другі момант прадстаўляе сабой беспрэцэдэнтнае наданне тытулу фараона гаспадару варожага да Егіпту царства Селяўкідаў - Антыёху III; пры гэтым імя апошняга было часткова апраўлена ў царскі картуш. 3 майго пункту гледжання, абодва моманты прадстаўлялі сабой вынік загадзя прадуманага рашэння. Прычынай наўмыснай замены імя Берэнікі іншым папулярным імем прадстаўніц царскага дому Пталямееў “Арсіноя” было нежаданне акцэнтаваць увагу на акце мацізабойства, фактычна ажыццёўленага пераможцам пры Рафіi за чатыры гады да прыняцця дэкрэту. Пры гэтым у іерагліфічным варыянце тэксту пастановы, які захаваўся вельмі фрагментарна, імя маці Пталямея IV указанае верна. Мяркую, што апошняя абставіна звязана з забаронай наўмыснага адкрытага скажэння ісціны пры выкарыстанні сакральнай па сваёй сутнасці іерагліфічнай пісьмовасці. У сваю чаргу, найменне Антыёха III фараонам магло служыць адлюстраваннем першых праяў незадаволенасці мясцовага насельніцтва Егіпту недастатковай увагай Пталямея IV да абавязкаў гаспадара Абедзвюх земляў. Гэткім экстравагантным чынам прадстаўнікі егіпецкага жрэцтва рабілі намёк на магчымасць з'яўлення іншага фараона, якім мог стаць самы блізкі сваяк Філапатара на жаночай лініi - Антыёх III.

Ключавыя словы: Дэкрэт Рафіi, Пталямей IV, Арсіноя, Берэніка II, Антыёх III

\section{А. Л. Зелінський \\ НАВМИСНІ "ПОМИЛКИ" \\ В ДЕМОТИЧНОМУ ВАРІАНТІ ДЕКРЕТУ РАФІї}

Після єгипетської перемоги в битві під Рафією (22 червня 217 р. до Р. Х.) і сприятливого для Країни Нілу завершення IV Сирійської війни (221-217 pp. до Р. Х.) місцевий жрецький синод ухвалив урочисту постанову на честь керівного фараона - Птолемея IV Філопатора (15 листопада 217 р. до Р. Х.). Йдеться про т. зв. Декрет Рафії, текст якого найкраще зберігся в демотичному варіанті (Cairo CG 50048; пор.: CG 31088). Саме в демотичному тексті цього документа наявні два моменти, які в сучасній історіографії, як правило, вважаються технічними помилками виконавців напису. Перший момент полягає в найменуванні Птолемея IV сином Арсиної, тоді як справжньою матір'ю цього царя була Береніка II. Другий момент являє собою безпрецедентне наділення титулом фараона володаря ворожого Єгипту царства Селевкідів - Антіоха III; до того ж ім'я останнього в кількох випадках було частково обрамлене в царський картуш. 3 мого погляду, обидва моменти були результатом заздалегідь продуманого рішення. Причиною навмисної заміни імені Береніки іншим популярним іменем представниць царського дому Птолемеїв - Арсиноя було небажання акцентувати акт матеревбивства, фактично здійснений переможцем битви під Рафією за чотири роки до ухвалення декрету. Водночас у дуже фрагментарно збереженому ієрогліфічному варіанті тексту постанови ім'я матері Птолемея IV вказано правильно. Вважаю, що це пов'язано із забороною навмисного відвертого викривлення істини при використанні сакрального за своєю сутністю ієрогліфічного письма. Своєю чергою найменування Антіоха III фараоном могло бути відображенням перших виявів невдоволення місцевого населення Сгипту недостатньою увагою Птолемея IV до обов'язків володаря Обох земель. У такий екстравагантний спосіб представники єгипетського жрецтва натякали на можливість появи іншого фараона, яким міг стати найближчий родич Філопатора по жіночій лінії - Антіох III.

Ключові слова: Декрет Рафії, Птолемей IV, Арсиноя, Береніка II, Антіох III 